\author{
ПОНЯТТЯ ІНШОМОВНОЇ КОМУНІКАТИВНОЇ КУЛЬТУРИ \\ Й ОСОБЛИВОСТІ ÏI РОЗВИТКУ
}

\title{
THE CONCEPT OF FOREIGN LANGUAGE COMMUNICATIVE CULTURE AND FEATURES OF ITS DEVELOPMENT
}

\begin{abstract}
у статті аналізується ореномен комунікативної культури як основи спілкування між людьми з різних континентів. Окрім того, культура спілкування іноземною мовою $є$ одним із важливих аспектів основної культури людини. Його варто розглядати як найважливіший компонент культури, де культура іноземної мови орункціонує як система для покращення формування профресійних та суспільно важливих рис особистості, а мова $є$ засобом спілкування та розвитку іншомовної культури спілкування.
\end{abstract}

Просресійна компетентність учителя - че динамічне поєднання знань, умінь і практичних навичок, способів мислення, професійних, ідеологічних та суспільних якостей, морально-етичних цінностей, які визначають здатність учителя виконувати професіійну діяльність. У иій діяльності вчитель $\epsilon$ активною темою спілкування: передавати й отримувати інсормацію від учнів, колег та батьків, установлювати з ними контакти, будувати стосунки на основі діалогу, розуміння та сприйняття внутрішнього світу дитини, прагнути до максимального розвитку здібностей кожного учня та забезпечення його емочійний комфорту в навчальному процесі. Тому важливою складовою частиною професійної компетентності вчителя є комунікативна компетентність, а одним із пріоритетних завдань вищої педагогічної освіти є фрормування професійно-педагогічної комунікативної компетентності вчителя, оскільки вона фуункціонує як духовно-моральний чинник та $\epsilon$ науковим змістом навчального процесу, де власне знання вчителя, його гуманне ставлення до оточення загалом та до кожного учня зокрема, душевна щедрість, розуміння та допомога учням відіграють основну роль.

У контексті інтеграції європейських систем освіти особливого значення набуває виховання комунікативної культури молоді, а опанування норм міжкультурного спілкування стає важливою передумовою для встановлення міжнародних контактів, доступу до світової бази знань, успішності здійснення профресійної, наукової і громадської діяльності, а також мобільності в сучасному світі.
Ключові слова: комунікативна культура глобалізація, освітній простір, навчальний прочес, педагогічна технологія.

The article dwells on the phenomenon of communicative culture as the basis of communication between people from different continents. In addition, the culture of communication in a foreign language is one of the important aspects of basic human culture. It should be considered as an important component of culture, where a foreign language functions as a system for improving the formation of professional and socially significant personality traits, and language is a means of communication and the development of a culture of foreign language communication.

Teacher's professional competence is a dynamic combination of knowledge, skills and practical skills, ways of thinking, professional, ideological and social qualities, moral and ethical values that determine the teacher's ability to perform professional activities. In this activity, the teacher has an active role in communication in order to transmit and receive information from students, colleagues and parents, establish contacts with them, build relationships based on dialogue, understanding and perception of the child's inner world, strive for maximum development of each student's abilities and emotional comfort in the learning process. Therefore, an important component of professional competence of teachers is communicative competence, and one of the priorities of higher pedagogical education is the formation of professional and pedagogical communicative competence of teachers, as it functions as a spiritual and moral factor and scientific content of the educational process. others in general and to each student individually, spiritual generosity, understanding and help to students play a major role.

In the context of integration of European education systems, the education of communicative culture of youth becomes especially important, and becomes an important issue for establishing international contacts, access to the world knowledge base, success of professional, scientific and social activities and mobility in the modern world.

Key words: communicative culture, globalization, educational space, educational process, pedagogical technology.

педагогічного університету

імені Михайла Коцюбинського

Постановка проблеми в загальному вигляді. Актуалізація проблеми комунікативної культури для майбутніх учителів, особливо вчителів іноземних мов, зумовлена низкою чинників: соціокультурними, пов'язаними із глобалізацією всіх сфер суспільного життя, міжнародною інтеграцією, зростанням спілкування та його динамікою, інтенсисрікацією медіа та розвитком сучасних засобів комунікації, користування мобільними телесронами, інтернетом тощо; педагогічними - освіта світового та європейського освітнього простору, удосконалення вітчизняної системи вищої освіти в контексті єдиного мультикультурного освітнього простору, посилення тенденцій гуманізації освітнього процесу та взаємодії між усіма учасниками, підвищення вимог до рівня загальної та професій- 
ної культури спілкування; інфрормаційними технологіями - інтенсивний розвиток інфрормаційних, телекомунікаційних і освітніх технологій у системі вищої освіти та спілкування в інтернеті, що вимагає не лише знання іноземних мов, а й розуміння культур різних людей світу.

Аналіз останніх досліджень і публікацій. Науковий інтерес до виховання в молоді комунікативної культури засвідчують численні праці, що виявляють міждисциплінарність вивчення даної проблеми.

Методологічні засади цієї проблеми розроблялись у таких напрямах: культурологічному (В. Біблер, М. Бубер), особистісно орієнтованому (В. Білоусова, К. Платонов, І. Якиманська), основ теорії комунікації (А. Добрович, Г. Кучинський, Ю. Лотман, Р. Якобсон); дослідження становлення загальної культури особистості (М. Александрова, В. Гриньова, І. Ісаєв, Л. Колмогорова, В. Межуєв), теорії та практики педагогічних технологій (В. Безпалько, О. Падалка, О. Пєхота, І. Підласий, О. Савченко), фрормування особистості студента в системі вищої освіти (О. Дубасенюк, Л. Бєлоусова, В. Оржеховська ).

Мета статті - науково обґрунтувати педагогічну технологію фрормування комунікативної культури.

Виклад основного матеріалу. Культура спілкування іноземною мовою розглядається як сукупність норм і правил, які регулюють спілкування людей у різних культурних контекстах. Характеризується наявністю комунікативного ідеалу, толерантним ставленням до співрозмовника як цінності, усвідомленням його індивідуальних якостей, власних комунікативних здібностей та навичок спілкування. Це система внутрішніх людських ресурсів, необхідна для існування в колі ситуацій міжособистісної взаємодії на різних рівнях [2].

Поліаспектний аналіз теоретичних засад фрормування комунікативної культури майбутніх учителів іноземної мови зумовив необхідність обґрунтування таких понять, як «культура», «комунікація», «спілкування», «професійно-педагогічна комунікація», «педагогічна культура», «профресійна культура педагога». За результатами теоретичного аналізу встановлено, що комунікативна культура педагога трактується як: діалогічний процес передачі інфрормації від суб'єкта до суб'єкта, один із важливих складників загальної і профресійно-педагогічної культури.

Культура спілкування давно розглядається як сукупність норм і правил процесу спілкування. Це, звичайно, важливі властивості, але вони не дозволяють представити френомен дослідження в усій його різноманітності, у його структурних та функціональних складових частинах. У процесі вирішення проблеми формування комунікативної культури важливо не лише опанування культурнопедагогічною спадщиною, а й включення педагога як суб'єкта культури, що несе рефрлексивне та сві- доме ставлення до світу цінностей, у процес інновацій та створення педагогічних інновацій. Самореалізація особистості в педагогічній діяльності, розвиток на цій основі індивідуально-творчої педагогічної системи, постійне прагнення до педагогічного пошуку та самовдосконалення - основні напрями фрормування комунікативної культури, актуалізують проблему 3 фрормування культури спілкування в учителя [3].

У своєму дослідженні П. Кендзьор стверджує, що культуру можна розглядати не тільки як матеріальні надбання та духовні цінності, створені людиною у процесі цілеспрямованої діяльності, а насамперед як відносини, що виникають під час накопичення, обміну, трансляції культурних смислів і значення [3, с. 32-35].

Якщо ж говорити про культурний розвиток, то це неможливо без міжкультурної комунікації, де культурну фрункцію виконує мова шляхом фрормування мовної особистості.

Отже, комунікативна культура вчителя представлена як складова частина загальної та профресійно-педагогічної культури, сукупність знань, умінь та комунікативних якостей особистості, що дає змогу налагодити суб'єкт-суб'єктну взаємодію 3 учнями й ефективно організувати навчальний процес, регулює комунікативну діяльність у процесі вирішення педагогічних проблем. Особливо важливими для комунікативної культури вчителя $€$ вміння та навички визначення і реалізації комунікативних завдань, моделювання комунікативної взаємодії, здібностей, здатності до співпереживання та дотримання культури спілкування в навколишньому середовищі.

Окрім того, френомен мовної особистості являє собою відображення культурної ідентичності у процесі мовної діяльності, де в центрі уваги іншомовної комунікативної культури - мовна особистість у всьому їі різноманітті: фрізичному, соціальному, інтелектуальному й емоційному.

Культура спілкування іноземними мовами розвиває здатність людини слухати, чути, аналізувати та розуміти співрозмовника, оцінювати і звертати увагу на деталі культурних цінностей в іншій культурі, порівнювати зі своїми та сприймати їх.

На думку М. Сергєєвої, «іншомовна культура»це інтегративне утворення, яке включає сукупність традиційних для рідної мови мовних, етнічних та поведінкових явищ і процесів.

$€$. Пассов характеризує іншомовну культуру як частину загальної культури людства, яку учень може опанувати у процесі іншомовної освіти в пізнавальному / культурологічному, психологічному, виховному / педагогічному та навчальному / соціальному аспектах.

Поняття «культура спілкування іноземною мовою» можна розглядати як систему знань і навичок, які необхідні для спілкування іноземною 
мовою, де воно є складовою частиною саморозвитку та прагнення до самовдосконалення через особистісні зміни, які дозволяють володіти когнітивними, емоційними способами поведінки під час комунікації.

У процесі виховання іншомовної культури спілкування молодь набуває знань про культуру народу, особливо про мову як її частину, розвиває свої комунікативні здібності. Тому під час вивчення іноземної мови варто не тільки зосереджуватися на фрормуванні мовних умінь і навичок учнів, а й ставити цілі більш глобального характеру, а саме вивчати культуру й особливості сучасного життя вивченою іноземною мовою, розширити мовні та культурні горизонти для молоді.

На думку Н. Битюцької, культура спілкування це інтегративне, цілісне явище, яке $є$ своєрідною професійно-педагогічною культурою та визначає напрям розвитку учнів, єдність особистісних цінностей, пізнавальні, технологічні й емоційно-творчі складові частини, здатність до спілкування та досягнення взаєморозуміння в індивідуальному та професійному аспектах [1, с. 7]. Дослідниця визначає особистісно-ціннісний компонент як сукупність цінностей та рис особистості, що виявляються в таких психічних якостях, як рефлексія, емпатія, децентралізація, особистісна ідентифрікація. Технологічний компонент являє собою опанування технології педагогічного спілкування, а пізнавальний компонент передбачає розвиток мовних, мовленнєвих і соціокультурних навичок, необхідних і достатніх для певного рівня; норми навчання міжкультурної комунікації; розвиток культури усного і письмового мовлення іноземною мовою в умовах формального та неформального спілкування.

Необхідно також зазначити, що культура мовлення $€$ одним із найважливіших розділів сучасного мовознавства, а також $є$ об'єктом дослідження сучасної педагогічної науки.

Щодо поняття «культура мовлення», то варто зазначити відсутність єдиного визначення в науковій літературі. 3 погляду лінгвістики культура мовлення визначається як «опанування усної та письмової літературної мови (правила вимови, наголос, лексика, граматика, стиль), а також уміння використовувати виразну мову в інших умовах спілкування відповідно до мети та змісту мовлення». Із цього можна зробити висновок, що культура мовлення містить два аспекти: мову та мовлення [4].

Зауважимо, що таке розмежування мови та культури мовлення характерне для зарубіжної науки. Так, Д. Розенталь визначає культуру мовлення, 3 одного боку, як «галузь фрілологічної науки, що вивчає мовленнєве життя суспільства в певну епоху і яка на науковій основі встановлює правила вживання мови як основного засобу людського спілкування». 3 іншого боку, автор розуміє мовленнєву нормативність відповідно до вимог, пропонованих для мовної групи в певний історичний період. Нормативне мовлення характеризують такі якості, як точність, ясність, чистота.

Б. Головін доповнює визначення культури мовлення в іншому його розумінні та пропонує, по-перше, виокремити систему комунікативних якостей мовлення, по-друге, ступінь володіння рідною мовою. Він стверджує у дослідженні, що «а) культура мовлення насамперед визначена своїми рисами та характеристиками, сукупність та система яких говорять про її комунікативну досконалість; б) культура мовлення - це сукупність людських умінь та знань, які забезпечують відповідне та просте використання мови для комунікативних цілей» [4].

Подібних поглядів дотримуються і Г. Винокур та Л. Скворцов, розрізняють два рівні опанування мовної культури: формування належного мовлення та мовленнєвої майстерності. Правильність мовлення передбачає дотримання носіями мови літературних норм, тоді як мовленнєва здатність $€$ здатністю вибирати 3 наявних альтернатив найбільш підходящі та стилістично відповідні, що задовольняє умовам комунікативної ситуації. Це означає, що мовленнєві навички вимагають певного рівня володіння законами рідної мови для мовленнєвої поведінки. Таке тлумачення терміна «культура мовлення» відповідає основним положенням дидактичних досліджень, згідно з якими культура мовлення визначається як «уміння правильно говорити <..>, вибирати мову та вираз відповідно до мети та ситуації спілкування, система вимог до використання мови в мовленні. Перейдемо безпосередньо до розгляду семантичних та структурних аспектів поняття «культура мовлення».

Дослідники визначають іншомовну комунікативну культуру як складний різновид іншомовної мовленнєвої діяльності викладача, метою якого $€$ створення сприятливих умов для продуктивної педагогічної взаємодії за допомогою ефективного педагогічного спілкування.

Узагальнюючи проаналізовані дослідження, комунікативну культуру майбутнього вчителя іноземних мов можна розглядати як системне утворення, яке виявляється в загальному вмінні зрозуміти того, хто навчається, і навчити його розуміти інших людей і себе, визначити як підсистему знань, комунікативних умінь та усвідомленості в межах системи міжкультурної комунікативної компетентності. Формування міжкультурної комунікативної компетентності включає, окрім відповідних знань, лексичних, граматичних і фронетичних навичок i вмінь у всіх видах мовленнєвої діяльності, суттєві для спілкування психологічний, соціокультурний і соціолінгвістичний компоненти [4, с. 91].

Висновки. Переосмислення педагогічної освіти з погляду культурологічного підходу висвітлює спектр нових проблем, пов'язаних із профе- 
сійно-особистісним становленням майбутнього вчителя як суб'єкта загальної та професійної культури. Реалізація цього підходу актуалізує культуротворчі фрункції вищої школи, характеризується переходом на нові педагогічні технології, орієнтовані на варіативність, індивідуально-творчі форми й методи підготовки майбутніх педагогів, використання інноваційних, зокрема інформаційнокомунікативних, засобів. Водночас вона постає як інститут розширеного відтворення і трансляції культури, забезпечує вихід за межі нормативної діяльності вчителя, здатність створювати й передавати цінності, стимулювати особистісно-професійний розвиток фрахівця.

Від того, як людина розмовляє, її культури й особливостей спілкування залежить ставлення оточення, фрормується думка про рівень обізнаності, вихованості чи освіченості особи. Тому іншомовна комунікативна культура постає однією із центральних проблем усіх часів, крізь призму якої визначають питання сприймання й розуміння людьми міжособистісних взаємин та своєрідність культур.

\section{БІБЛІОГРАФІЧНИЙ СПИСОК:}

1. Артеменко О. Педагогічні умови розвитку професійної успішності майбутнього вчителя-фрілолога. Умань : ПП Жовтий О.О., 2011. № 4. Ч. 2. С. 50-54.

2. Грушевицька Т. Основи міжкультурної комунікації : підручник для вузів. Москва : Юніті-Дана, 2002. 352 c.

3. Кендзьор П. Полікультурне виховання учнів у системі діяльності загальноосвітнього навчального закладу (теорія і методика) : дис. ... докт. пед. наук: 13.00.07. Київ, 2017. 425 с.

4. Островая В. Педагогические условия фрормирования коммуникативной компетентности в профессионально-корпоративной среде. Человек и образование : журнал. 2012. № 2. С. 153-157. 